\title{
Introduction: Silence and Silencing in Children's Literature
}

The theme of "Silence and Silencing" for the IRSCL Congress 2019 in Stockholm struck a chord with many scholars of children's literature, resulting in hundreds of paper presentations. The papers explored various uses and forms of silence while also detailing figurative and literal strategies of silencing, and the ensuing critical discussion was both lively and productive. Further enriching the polyphony of scholarly responses, many of the presenters also heeded the call to develop their papers into articles: International Research in Children's Literature (IRCL) released a special issue on the topic in 2020 while Barnboken published a theme that stretched across two volumes 2020-2021. Most of these articles were then collected and supplemented with the Congress keynote lectures in a 600-page anthology, published by Makadam and the Swedish Institute for Children's Books in 2021.

The Barnboken theme "Silence and Silencing in Children's Literature" consists of ten articles, each addressing different manifestations of silence and silencing in children's and young adult literature. The contributions cover a broad range of primary material - from children's classics and young adult fiction to contemporary picturebooks and video games - as well as a wide variety of theoretical approaches such as trauma studies, queer theory, posthumanism, and aetonormativity, to name some of the central perspectives.

In her article "The Silence of Fragmentation: Ethical Representations of Trauma in Young Adult Holocaust Literature", Talia E. Crockett discusses narrative silences and elisions as an ethical and aesthetical strategy to express the inexpressible: the horror and trauma of the Holocaust. The evolving use of silence and fragmentation in Holocaust literature is discussed in three young adult novels from the last thirty-five years: Jane Yolen's Briar Rose (1992), Marianne Fredriksson's Simon och ekarna (Simon and the Oaks, 1985), and Sharon Hart-Green's Come Back for Me (2017). Crockett argues that the textual silences that are depicted in these novels also replicate the fragmented experience of the death camps.

(C2021 E. Druker, B. Sundmark, Å. Warnqvist, M. Österlund. This is an open access article distributed under the terms of the Creative Commons CC-BY-NC 4.0 License (https:/ / creativecommons.org/ licenses/by-nc/4.0/), permitting all non-commercial use, distribution, and reproduction in any medium, provided the original work is properly cited.

Citation: Barnboken - tidskrift för barnlitteraturforskning/Barnboken: Journal of Children's Literature Research, Vol. 44, 2021 http://dx.doi.org/10.14811/clr.v43.643 
Similarly, Mateusz Świetlicki's article “'It felt better to stay quiet': Miming as a Non-Verbal Way of Coping with Trauma in Kathy Kacer's Masters of Silence (2019)" explores how Kacer's World War II novel presents silence as an effect of traumatic experiences, while also depicting non-verbal coping strategies as potentially empowering. The trauma of being separated from his parents during the war causes the young Jewish protagonist Henry to stop speaking, and Świetlicki demonstrates how Henry uses miming and journal writing to work through his trauma. Thereby, Świetlicki argues, Kacer's novel serves the purpose of conveying "next-generation" memory of the Second World War to her readers while also drawing attention to the potential of the non-verbal.

The depiction of silence as a symptom and cause of trauma is also discussed by Helen King in her article "Seeking Asylum, Speaking Silence: Speech, Silence and Psychosocial Trauma in Beverley Naidoo's The Other Side of Truth". The article investigates trauma, but also survival strategies in Naidoo's young adult novel The Other Side of Truth (2000). Contextualising the novel with the help of archival material, King's study underlines the ambivalent role silence and speech plays in the novel. She demonstrates how Naidoo in the portrayal of the Nigerian siblings Sade and Femi who flee to Britain simultaneously depicts speech as the beginning of personal healing and social change, but at the same time as a costly act with the potential to cause trauma.

In her article "Nature Unnested: Kin and Kind in Switched Egg Children's Stories", Kathleen Forrester examines the complex use of Hans Christian Andersen's switched egg narrative in The Ugly Duckling in two contemporary picturebooks, Peter Parnell and Justin Richardson's And Tango Makes Three (2005) and Emily Gravett's The Odd Egg (2008). Drawing on queer, feminist, and posthumanist theories, the material-symbolic presence of the egg is treated as a generative site for examining the construction and perpetuation of notions of kin and kind, and, at the same time, acknowledging the concurrent conservative and radical potentialities of children's literature. As Forrester shows, the egg switch trope offers the possibility of "unnesting" dominant narratives by voicing silenced or censored ideas of kin and kind.

Lance Weldy also focuses on a character study in his article "The Queerness of the Man-Child: Narcissism and Silencing in Astrid Lindgren's Karlson on the Roof Series", where he discusses the charming but narcissistic character Karlson from Astrid Lindgren's Karlson on the Roof trilogy (1955-1968). As Weldy demonstrates, 
Karlson is a "man-child" character who can be read as queer in that he disrupts traditional boundaries of the child/adult binary, disregarding societal expectations of what it means to be an adult by moving freely between these two categories and thereby subverting their meaning.

Aetonormativity and ideologies surrounding "the child" and childhood are also discussed in Emma Reay's article "Secrets, Stealth, and Survival: The Silent Child in the Video Games Little Nightmares and INSIDE". Here, Reay discusses how the child figure is constructed in two wordless video games - Little Nightmares (Tarsier Studios, 2017) and INSIDE (Playdead, 2016) - focusing specifically on the connection between the child's "blankness" and its silence, and how these related qualities establish the child-characters as sites of semantic complexity and contradiction. Reay argues that the player-avatar relationships in these games shed new light on some of the fundamental contradictions that characterize adult normativity and child alterity.

Political silencing is investigated in Sara Pankenier Weld's article "The Silencing of Children's Literature: The Case of Daniil Kharms and the Little Old Lady". Discussing the Russian avant-garde writer Daniil Kharms, who wrote for both children and adults in the 1920s and 1930s, before his premature death as a result of repression by the Soviet regime, Pankenier Weld shows how children's literature can be studied not only for its own sake, but also in order to illuminate our understanding of literature for adults. To demonstrate the arbitrariness of subdividing an author's literary production into mutually exclusive categories, Pankenier Weld discusses the motif of the little old lady, a marginal figure who recurs in Kharms's writings regardless of audience and shows how the character functions both as an embodiment of writing itself but also, and more importantly, as an expression for the silencing, marginalization, and censorship of the author in a repressive societal context.

Joshua Simpson also discusses political silencing in his article "Silence and Absence in the Political Discourse on Section 28 and Children's Literature in the United Kingdom". He analyzes the uses of children's literature in the 1986-1988 British Parliamentary debates that led up to Section 28, which prohibited the "promotion of homosexuality" by local authorities, showing how silence and absence were used as a discursive strategy by supporters of the law during the debates. As Simpson demonstrates, politicians in favour of the law would misrepresent or omit the content of children's books featuring gay characters to support their argument. 
Another article that exposes silencing strategies, but in this case those that support the killing and eating of animals, is Marianna Koljonen's "Breaking the Silence about the Animals We Eat: Representations of the Inherent Value of Nonhuman Animals in Children's Picturebooks". Koljonen dissects socially and culturally maintained silences regarding animal-farming and the meat industry in relation to animal picturebooks, demonstrating how these silencing strategies are countered in two Nordic picturebooks: Älskade lilla gris (Dear Little Pig) by Ulf Nilsson and Eva Eriksson (1982), and Kinkkulin jouluyllätys (Little Ham's Christmas Surprise) by Teija Rekola and Timo Kästämä (2010).

Ann-Sofie Persson's article "Narrative Strategies Giving Voice to the Silenced Subject: The Horse in Fiction for Children" also uses a posthumanist approach and discusses how a framework of silence versus voice, and othering versus anthropomorphizing, co-exists within different narrative strategies in stories about horses. Persson studies two Swedish book series: the stories of Vitnos (1971-1980) by Marie Louise Rudolfsson, and the Klara books (1999-2008), showing that regardless of the narrative form chosen, these stories depict horse and human as each other's Other.

As this brief overview of the ten articles shows, the theme of silence and silencing is a rich area of investigation. The great variety the articles display in terms of both material and theoretical approaches underlines the complexity of the theme, pointing to the multitude of forms that silence and silencing can take in the context of children's literature and the many different implications of silence as narrative device, motif, or analytic tool. With this theme, we hope to demonstrate not only the importance of exploring the silences of children's and young adult literature, but also the rewards of listening closely to what has been left unsaid.

Guest editors

Elina Druker (Professor, Stockholm University), Björn Sundmark (Professor, Malmö University), As a Warnqvist (Docent, the Swedish Institute for Children's Books), and Mia Österlund (Docent, Åbo Akademi University) 